Illinois State University

ISU ReD: Research and eData

$9-2020$

\title{
The Value of Information in Professional Settings is Experienced through Relationships and Networks
}

Rachel E. Scott

Illinois State University, rescot2@ilstu.edu

Follow this and additional works at: https://ir.library.illinoisstate.edu/fpml

Part of the Library and Information Science Commons

\section{Recommended Citation}

Scott, Rachel E., "The Value of Information in Professional Settings is Experienced through Relationships and Networks" (2020). Faculty and Staff Publications - Milner Library. 119.

https://ir.library.illinoisstate.edu/fpml/119

This Article is brought to you for free and open access by the Milner Library at ISU ReD: Research and eData. It has been accepted for inclusion in Faculty and Staff Publications - Milner Library by an authorized administrator of ISU ReD: Research and eData. For more information, please contact ISUReD@ilstu.edu. 


\title{
Evidence Based Library and Information Practice
}

\section{Evidence Summary}

\section{The Value of Information in Professional Settings is Experienced through Relationships and Networks}

\author{
A Review of: \\ Reviewed by: \\ Rachel E. Scott \\ Associate Dean for Information Assets \\ Illinois State University \\ Normal, Illinois, United States of America \\ Email: $\underline{\text { rescot2@ilstu.edu }}$
}

Sharun, S. (2019). Exploring value as a dimension of professional information literacy. Journal of Information Literacy, 13(2), 26-40. https://doi.org/10.11645/13.2.2627

Received: 21 Apr. 2020

Accepted: 8 July 2020

\begin{abstract}
(a) 2020 Scott. This is an Open Access article distributed under the terms of the Creative Commons-AttributionNoncommercial-Share Alike License 4.0 International (http://creativecommons.org/licenses/by-nc-sa/4.0/), which permits unrestricted use, distribution, and reproduction in any medium, provided the original work is properly attributed, not used for commercial purposes, and, if transformed, the resulting work is redistributed under the same or similar license to this one.
\end{abstract}

DOI: 10.18438/eblip29766

\begin{abstract}
Objective - To critically explore the frame "Information has Value" in a workplace setting.

Design - Semi-structured interviews.

Setting - Community health centre in Canada.

Subjects - Seven health and human services staff members serving vulnerable, urban youth ages 12 to 24 .
\end{abstract}

Methods - The researcher employed phenomenography to analyze interviews and to identify categories of information practice.
Main Results - Four categories of information practice emerged: resourcing, referring, outsourcing, and advocating. The researcher identified the value of information as central to participants' experience of information practice in the workplace. Subjects' understanding of the nature and significance of value was situated within personal relationships and professional networks.

Conclusion - The study demonstrated that a specific aspect of information literacy can be successfully investigated to highlight its complexity and to show how it is experienced in a specific setting. A second conclusion was the centrality of interpersonal relationships to how value is experienced in professional 
information practice. The researcher recommends further study exploring relational value and in the sociocultural practice of information literacy.

\section{Commentary}

Much of the scholarship on information literacy focuses on students and information professionals and is conducted within educational institutions. By conducting this study in a community health centre, Sharun continues the work of Lloyd (2009) and Hicks (2015) to investigate information practices within a professional context in order to contribute to the development of a more holistic sociocultural theory of information literacy.

Koufogiannakis, Booth, and Brettle's ReLIANT (Reader's guide to the Literature on Interventions Addressing the Need for education and Training) instrument supports the critical assessment of interventions in library and information science (2006). I employed ReLIANT to evaluate the design, results, and relevance of Sharun's study. The researcher explained the appropriateness of phenomenography as a research methodology within LIS and cited relevant studies to convey how it has been effectively employed. Sharun took important steps to confirm the validity of the coding and results. The researcher recorded and transcribed the interviews before sending transcripts to participants for verification. Additionally, the category names came from participant language, and the categories were subsequently validated when the author asked participants to provide definitions and examples. The author does not indicate if any software was employed to facilitate coding the transcripts or analyzing the qualitative data.

The results section presents a definition and discussion of each of the four categories of information practice identified. Long quotes from participants expound on how they experience each of these categories in their daily work and highlight the relational aspect of value in their information practices. By making explicit a connection between the study's findings and the ACRL framework, the author makes the article more immediately relevant to information professionals interested in that document.

This study meets its stated objective of critically exploring value in the information practice of health and human services employees. By investigating a specific aspect of information practice in the workplace, this study adds to the literature by contributing to the development of a multifaceted sociocultural theory of information literacy. A more specific and robust methods section may have encouraged readers to adopt the study to local settings. Although the study is unlikely to be reproducible in its specific context, the richness of the qualitative data and the author's work to confirm the validity of the responses and analysis add to the value of this study.

\section{References}

Hicks, A. (2015). Drinking on the job: Integrating workplace information literacy into the curriculum. LOEX Quarterly, 41(4), 9-15. https://commons.emich.edu/loexquarte rly/vol41/iss $4 / 4$

Koufogiannakis, D., Booth, A., \& Brettle, A. (2006). ReLIANT: Reader's guide to the literature on interventions addressing the need for education and training. Library \& Information Research, 30(94), $44-51$. https://www.lirgjournal.org.uk/index. php/lir/article/view/271

Lloyd, A. (2009). Informing practice: Information experiences of ambulance officers in training and on-road practice. Journal of Documentation, 65(3), 396-419. https://doi.org/10.1108/00220410910952 $\underline{401}$ 